\title{
METODE PENDIDIKAN AGAMA ISLAM SEKOLAH DASAR
}

\author{
Ayatullah \\ STIT Palapa Nusantara Lombok-NTB \\ Email. ayatullahayeq@gmail.com.
}

\begin{abstract}
Through the innovative method of Islamic education learning, the learning atmosphere in the classroom is not stuck in a rigid and monotonous atmosphere. So that students will more easily understand the material delivered. Susana learning will make students unsaturated to receive material from teachers. This research uses descriptive qualitative approach. To obtain valid and accurate data, the author uses three data collection techniques. One tool of Islamic education in elementary school is the method of Islamic religious education, which by using the right method then the teachings of religion can be absorbed by students with the best. The right method will determine the effectiveness and efficiency of learning. The meaning in Islam itself has also been taught about the method of teaching, because the Islamic religion is actually not just a system of theology alone, but it is a complete civilization.
\end{abstract}

\section{Kata kunci: Metode Pendidikan Agama Islam}

\section{Pedahuluan}

Era globalisasi merupakan produk pembangunan yang dimotori oleh Barat selaku pemegang konstelasi dunia dalam bidang iptek dan ekonomi. Keberhasilan Barat tidak terlepas dari peran lembaga pendidikannya. Globalisasi membawa masyarakat modern kepada krisis spiritual. Dalam konteks seperti ini, Pendidikan Agama Islam laksana jembatan penyelamat bagi masyarakat modern dari krisis spiritual. ${ }^{1}$

Sebagai dasar Pendidikan Agama Islam adalah Al-Qur'an dan Sunnah Nabi yang jadi rujukan untuk mencari membuat dan mengembangkan konsep, prinsip, teori dan teknik Pendidikan Agama Islam. Artinya rasa dan pikiran manusia yang bergerak dalam kegiatan pendidikan tersebut bertolak dari keyakinan tentang benarnya Al-Qur'an dan Sunnah Nabi. ${ }^{2}$ Pendidikan Agama Islam merupakan warisan dan perkembangan budaya manusia yang bersumber dan berpedoman ajaran Islam dalam rangka terbentuknya kepribadian utama menurut Islam. $^{3}$

\footnotetext{
${ }^{1}$ Abdullah Idi \& Toto Suharto, Revitalisasi Pendidikan Islam (Yogyakarta : Tiara Wacana, 2006), hlm.102- 103 .

${ }^{2}$ Sanusi Uwes, Visi dan Pondasi Pendidikan( Dalam Perspektif Islam), (Jakarta: Logos Wacana Ilmu, 2003) hlm. 6

${ }^{3}$ Fatah NC Sejarah Pendidikan Islam. Syukur,. (Semarang: Pustaka Rizqi Putra, 2012), hlm.11.
} 
Pendidikan Agama Islam adalah sebagai mata pelajaran yang wajib diajarkan dalam kurikulum sekolah mulai dari pendidikaan dasar sampai perguruan tinggi. ${ }^{4}$ Legalitas tersebut, tercantum dalam Undang-Undang dan Sistem Pendidikan Nasional No. 20 Tahun 2003 tentang Sistem Pendidikan Nasional (UUSISDIKNAS) Bab II, Pasal 30 Ayat (1), (2) dan (3) bunyinya adalah:

"Pendidikan keagamaan diselenggarakan oleh Pemerintah dan/atau kelompok masyarakat dari pemeluk agama, sesuai dengan peraturan perundang-undangan. Pendidikan keagamaan berfungsi mempersiapkan peserta didik menjadi anggota masyarakat yang memahami dan mengamalkan nilai-nilai ajaran agamanya. Pendidikan keagamaan dapat diselenggarakan pada jalur pendidikan formal, nonformal, dan informal'.

Jadi selain di sekolah Islam, Pendidikan Agama Islam juga diselenggarakan di sekolah umum, baik di negeri maupun swasta, mulai dari SD sampai SMA/K. Pendidikan Agama Islam di sekolah umum dikemas dalam mata pelajaran Pendidikan Agama Islam (PAI) yang terdiri lima aspek, yaitu Akidah, Akhlak, Al-Qur'an dan Hadits, dan Sejarah Kebudayaan Islam.

Pendidikan Agama Islam di sekolah/madrasah bertujuan untuk menumbuhkan dan meningkatkan keimanan melalui pemberian dan pemupukan pengetahuan, pengetahuan, penghayatan, pengamalan, serta pengalaman peserta didik tentang agama Islam sehingga menjadi manusia muslim yang terus berkembang dalam hal keimanan, ketakwaannya, berbangsa dan bernegara, serta untuk dapat melanjutkan jenjang pendidikan yang lebih tinggi. ${ }^{5}$

Tujuan Pendidikan Agama Islam sangat mendukung dengan tujuan Pendidikan Nasional yang tercantum dalam Undang Undang Sistem Pendidikan Nasional (UU SISDIKNAS) No. 20 Tahun 2003 BAB II pasal 3 yaitu mengembangkan kemampuan mencerdaskan kehidupan bangsa, bertujuan untuk berkembangnya potensi peserta didik agar menjadi manusia yang beriman dan bertaqwa kepada Tuhan Yang Maha Esa,

\footnotetext{
${ }^{4}$ Hasbullah, Dasar-dasar Ilmu Pendidikan Umum dan Agama Islam. (Jakarta: Rajawali Pers.2008)
} hlm 150

${ }^{5}$ Abdul Majid dan Dian Andayani, Pendidikan Agama Islam Berbasis Kompetensi: Konsep dan Implementasi Kurikulum 2004, (Bandung : Remaja Rosdakarya, 2004), hlm. 132 
berakhlak mulia, sehat, berilmu, cakap, kreatif mandiri dan menjadi warga yang berdemokratis serta bertanggung jawab ${ }^{6}$

Menurut Zuhairini, yang dikutip oleh Muhaimin menjelaskan bahwa dalam Islam pada mulanya pendidikan disebut dangan kata "Ta'lim" dan "Ta'dib" mengacu pada pengertian yang lebih tinggi, dan mencakup unsur-unsur pemgetahuan ('ilm) pengajaran (Ta'lim) dan bimbingan yang baik (Tarbiyah).

Sedangkan menurut Langgulung (1997), pendidikan Islam itu setidak-tidaknya tercakup dalam delapan pengertian, yaitu Al-tarbiyah al-diniyah (pendidikan keagamaan), Ta'lim al-din (pengajaran agama), Al-ta'lim al-diny (pengajaran keagamaan), Al-ta'lim al-Islamy (pengajaran keislaman), Tarbiyah al-muslimin (pendidikan orang-orang Islam), Al-tarbiyah fi al-Islam (pendidikan dalam Islam), Al-tarbiyah 'inda al muslimin (pendidikan di kalangan orang-orang Islam), dan Al-tarbiyah al-Islamiyah (pendidikan Islami) ${ }^{7}$.

Di kalangan masyarakat Indonesia, istilah "pendidikan" mendapatkan arti yang sangat luas. Kata-kata pendidikan, pengajaran, bimbingan dan pelatihan, sebagai istilahistilah teknis dan tidak lagi dibeda-bedakan oleh masyarakat kita, tetapi ketiga-tiganya lebur menjadi satu pengertian baru tentang pendidikan. ${ }^{8}$

Dalam dunia pendidikan proses belajar mengajar yang disingkat menjadi PBM, ada sebuah ungkapan populer yang dikenal dengan: "metode jauh lebih penting dari materi". Demikian urgennya metode dalam proses pendidikan dan pengajaran, sebuah proses belajar mengajar (PBM) bias dikatakan tidak berhasil bila dalam proses tersebut tidak menggunakan metode, karena metode menepati posisi kedua terpenting setelah tujuan dari sederetan komponen komponen pembelajaran, yaitu tujuan, metode, materi, media, dan evaluasi.

Salah satu alat pendidikan agama Islam yakni metode pendidikan agama Islam, yang mana dengan menggunakan metode yang tepat maka ajaran-ajaran agama dapat diserap oleh siswa dengan sebaik-baiknya. Metode yang tepat akan menentukan efektifitas dan efisiensi pembelajaran. Seiring dengan itu seorang pendidik/ guru dituntut agar cermat memilih dan menetapkan metode apa yang tepat digunakan untuk menyampaikan materi pelajaran kepada siswa, karena dalam proses belajar mengajar dikenal ada beberapa

\footnotetext{
${ }^{6}$ UU SISDIKNAS 2003 (Bandung: Citra Umbara, 2006), hlm. 76.

${ }^{7}$ Muhaimin, M. A, Paradigma Pendidikan Islam (Bandung: PT Remaja Rosdakarya, 2002) hlm 36

${ }^{8}$ ibbid
} 
macam metode, antara lain: metode ceramah, diskusi, tanya jawab, demonstrasi, bernyanyi, bermain peran, pemberian tugas, drill/latihan dan lain sebagainya. Semua metode tersebut dapat diaplikasikan didalam proses belajar mengajar. Ada beberapa faktor yang perlu diperhatikan dalam memilih dan mengaplikasikan sebuah metode pengajaran : 1) Tujuan yang hendak dicapai, 2) Kemampuan guru, 3) Anak didik, 4) Situasi dan Kondisi dimana berlangsung, 5) Fasilitas yang tersedia, 6) Waktu yang tersedia, 7) Kebaikan dan Kekurangan sebuah metode ${ }^{9}$

Metode yang ditetapkan oleh seorang guru dapat berdaya guna dan berhasil guna jika mampu dipergunakan untuk mencapai tujuan pendidikan yang telah ditetapkan. ${ }^{10}$ Pendidikan yang diajarkan pada anak harus sesuai dengan kemampuan yang ada pada mereka. Sebagai seorang guru ataupun orang tua harus pintar-pintar memilah dan memilih metode yang sesuai untuk perkembangan anak yang usianya masih tergolong sangat muda. Sedangkan pendidikan itu sendiri tidak mengenal tempat dan usia.

Dengan metode pembelajaran, proses penerimaan siswa terhadap pelajaran akan lebih berkesan secara mendalam, sehingga membentuk pengertian dengan baik dan sempurna. Siswa juga dapat mengamati dan memperhatikan apa yang diperlihatkan selama pelajaran berlangsung. ${ }^{11}$ Belajar yang hanya mengandalkan indera pendengaran mempunyai beberapa kelemahan, padahal hasil belajar seharusnya disimpan sampai waktu yang lama. Dengan demikian, suasana lingkungan belajar yang kondusif dan terarah dapat tercermin lewat kreatifitas dan daya fikir yang kritis siswa sehingga kegiatan belajar mengajar yang berlangsung dari awal hingga akhir dapat berjalan proporsional, seimbang dan teratur.

Pembelajaran akan berlangsung efektif dan efisien apabila didukung dengan peran guru dalam mengatur strategi pembelajaran. Dalam menyajikan metode pembelajaran, seorang guru tidak boleh terpaku hanya pada satu jenis teknik saja. Paradigma lama yang menganggap guru sebagai satu-satunya sumber dan pusat informasi, serta siswa hanyalah ibarat gelas kosong yang dapat diisi apa saja sesuai dengan kemauan guru atau diibaratkan kertas puth yang dapat ditulis apa saja menurut kehendak guru, mungkin perlu ditinjau kembali.

\footnotetext{
${ }^{9}$ Armai Arief, Pengantar Ilmu dan Metodologi Pendidikan Islam, (Jakarta: Intermasa, 2002), hlm. 109. 3

10 H.Hamdani Ihsan, H.A.Fuad Ihsan, Filsafat Pendidikan Islam, (Bandung: Pustaka Setia, 2001), hlm. 163.

${ }^{11}$ Roestiyah NK, Strategi Belajar Mengajar, (Jakarta: Rineka Cipta, 2008), hlm. 1.
} 
Ketika siswa masuk ke dalam kelas, guru harus sadar bahwa dalam diri siswa itu sudah tertanam dan terbangun informasi, pengetahuan dan pengalaman yang mereka peroleh di luar kelas dari interaksi dengan lingkungannya. Dengan begitu, guru juga menyadari bahwa ia bukanlah satu-satunya pusat informasi, melainkan terdapat banyak media, cara dan sumber yang dapat dijadikan siswa untuk memperoleh informasi. Faktor yang berasal dari dalam diri peserta didik terutama kemampuan yang dimilikinya. Faktor kemampuan peserta didik besar sekali pengaruhnya terhadap hasil belajar yang dicapai. Disamping kemampuan, faktor lain yang juga mempunyai kontribusi terhadap hasil belajar seseorang adalah factor fisiologis, psikologis, minat, bakat, motivasi, kematangan, dan lainlain $^{12}$.

\section{Metode}

Secara etimologis, metode berasal dari bahasa Yunani, yaitu "methodos". Kata ini terdiri dari dua suku kata, yaitu "metha" yang berarti melalui atau melewati, dan "hodos" yang bearti jalan atau cara. Jadi meode berarti suatu jalan yang dilalui untuk mencapai tujuan $^{13}$. Dalam Kamus Besar Bahasa Indonesia, metode adalah "cara yang telah diatur dan dipikirkan baik-baik untuk mencapai suatu maksud dalam ilmu pengetahuan dan sebagainya." 14

Metode menurut J.R David dalam Teaching Strategies for College Class Room (1976) adalah a way in achieving something "cara untuk mencapai sesuatu". Untuk suatu strategi digunakan seprangkat metode pengajaran tertentu. Dalam pengertian demikian maka metode pengajaran menjadi salah satu unsure dalam strategi belajar mengajar. Unsur seperti belajar, kemampuan guru dan siswa, media pendidikan, materi pengajaran, organisasi adalah waktu tersedia, kondisi kelas dan lingkunggan merupakan unsure-unsur yang mendukung strategi belajar-mengajar. Dalam bahasa arab dikenal dengan istilah thariq (jalan-cara) ${ }^{15}$

\footnotetext{
${ }^{12}$ Nana Sudjana CBSA, Cara Belajar Siswa Aktif dalam Proses Balajar Mengajar (Bandung, Sinar Baru Algensindo, 1996) hlm 6

${ }^{13}$ Ramayulis, Metodologi Pengajaran Agama Islam, (Jakarta: Kalam Mulia, 1990), hlm 104

${ }^{14}$ Suharso dan Ana Retnoningsih, Kamus Besar Bahasa Indonesia, (Semarang: Widya Karya, 2009), hlm.321

15 Abdul Majid, Belajar dan Pembelajaran Pendidikan Agama Islam, (Penerbit PT Remaja Rosdakarya Bandung, 2012) hlm 131
} 
Jadi metode adalah suatu cara yang dipergunakan untuk mrncapai tujuan yang telah ditetapkan. Dalam proses interaksi belajar mengajar, metode diperlukan seorang guru bervariasi sesuai dengan tujuan yang ingin dicapai setelah pengajaran berakhir. Seorang guru tidak akan dapat melaksanakan tugasnya bila dia tidak menguasai satu pun metode mengajar yang telah dirumuskan dan dikemukakan para ahli pendidikan. ${ }^{16}$

Dalam proses interaksi belajar mengajar, guru tidak harus terpaku dengan mengunakan satu metode, tatapi harus mengunakan metode bervariasi agar jalan pengajaran tidak membosankan, tetapi menarik perhatian anak didik. Meski pengunaan metode yang bervariasi tidak akan menguntungkan proses interaksi belajar mengajar bila penggunaan metode tidak tepat dengan situasi yang mendukunnya. Disinilah kompetensi guru diperlukan dalam pemilihan metode yang tepat. Oleh karena itu, pemilihan dan pengunaan metode yang bervariasi tidak selamanya menguntungkan bila guru mengabaikan factor-faktor yang mempengaruhi pengunaannya.

Menurut Winarno Surakhmad mengemukakan lima macam factor yang mempengaruhi pengunaan metode mengajar sebagai berikut: Pertama, Tujuan yang bebagai-bagai jenis dan fungsinya. Kedua, Anak didk yang berbagai-bagai tingkat kematangannya. Ketiga, Situasi yang berbagi-bagai keadaannya. Keempat, Fasilitas yang berbagai-bagai kualiatas dan kuantitasnya. Dan Pribadi guru serta kemampuan profisionalnya yang berbeda-beda. ${ }^{17}$

Mengajar itu sendiri menurut Ing. S. Ulih Bukti Karo Karo adalah menyajikan bahan pelajaran oleh orang kepada orang lain agar orang lain itu menerima, menguasai dan mengembangkannya. Didalam lembaga pendidikan, orang lain yang disebut diatas disebut sebagai murid/siswa dan mahasiswa, yang dalam proses belajar mengajar aagar dapat menerima, menguasai dan lebih-lebih mengembangkan bahan pelajaran itu, maka cara-cara mengajar serta cara belajar haruslah setepat-tepatnya dan seefisien serta seefektif mungkin $^{18}$.

Satu hal yang perlu diperhatikan guru, pengunaan metode mengajar yang bervariasi tetap beroriantasi pada tujuan pengajaran. Tujuan inilah sebagai pedoman dalam proses interaksi belajar mengajar untuk suatu bidang studi. Ini berarti guru sebaiknya

\footnotetext{
1994), hlm

${ }^{16}$ Syaiful Bahri Djamarah, Prestasi Belajar dan Kompetensi Guru, (Usaha Nasiaonal, Surabaya,

${ }^{17}$ Ibbid hlm 71

${ }^{18}$ Slameto, Belajar \& Faktor-faktor Yang Mempengaruhi, (Penerbit Rineka Cipta, Jakarta, 2010), hlm 65
} 
mempersiapkan bahan, sarana, metode, dan evaluasi yang dapat mencapai tujuan tersebut. Sumau itu perlu dipersiapkan dalam perencanaan mengajar, yang disebut satuan pelajar. ${ }^{19}$

Begitu kita bicara tentang metode terus terbayang dikepala kita dua bentuk atau dau jenis metode itu, yaitu metode perolehan (acquisition) ilmu dan metode pemindahan atau penyampian (transmisition) ilmu itu. Bagian ini akan membatasi diri pada jenis yang kedua yaitu metode penyampian atau pemindahan (transmisition) ilmu itu, sesuai permintaan pembuat seminar ini. Sedangkan metode perolehan (acquisition) ilmu harus dibicarakan dalam kertas tersendiri secara mendalam dan secara sepintas lalupun telah dibicarakan dibagain yang lalu. ${ }^{20}$

Membicarakan metode penyampian atau pemindahan ilmu-ilmu itu dari generasi, terus perhatian kita tertuju kepada soal makro dan mikro. Dari segi makro harus ditinjua proses pemindahan itu dari segi lembaga-lembaga asosiasi dan asas-asas lain yang menopangnya seperti asas-asas historis, politik dan tatalaksana, ekonomi, struktur social di mana pendidikan itu beroperasi. Di dunia modern lembaga-lembaga seperti media masa lebih dianggap sebagai lembaga yang paling dominan dalam proses pemindahan itu disamping lembaga-lembaga formal seperti sekolah dan universitas ${ }^{21}$.

Dari segi mikro yang paling menarik perhatian ialah bagaimana menyampaikan isi kepala seorang guru kepada kepala murid-murid, kalau memamng ilmu itu berbeda di kepala. Walaupun ini memang kelihatanya lebih mudah dikontrol, dalam pengertian kalau sekian modalnya maka mudah dilihat hasilnya, sebab setiap sekolah berjalan menurut ketentuan dan peraturan yang ketat dari segi jumlah murid setiap sekolah dan kelas, rasio guru-murid, lama waktu belajar, silabus yang harus diikuti, ujian yang harus diikuti, tahap munimun yang harus dicapai, dan lain-lain sebagainya. Ini memang dari segi teori kelihatan lebih mudah dikontrol dari pada pemindahan pengetahuan yang tidak formal melalui khotbah, masa media, dan pengajaran yang tidak teratur. Tetapi dari segi praktik inipun tidak semudah yang nampak itu. Sebab jiwa murid yang menerima ilmu itu bukanlah seperti tong kosong yang menerima apa saja yang dituangkan kepadanya, suka atau tidak suka. Didalam jiwa ada struktur dan aturan yang harus diikuti barulah isi pengajaran itu

\footnotetext{
${ }^{19}$ Ibbid hlm 76

${ }^{20}$ Hasan Langgulung, Pendidikan Islam Menghadapi Abad Ke-21, (Pustaka Al Husna, Jakarta, 1988), hlm 42

${ }^{21}$ Ibbid hlm
} 
bias diterima. Kalau tidak, maka pengajaran itu sia-sia saja. Jadi proses pemindahan gagal adanya. $^{22}$

\section{Pendidika Agama Islam}

Pendidikan agama Islam adalah upaya sadar dan terencana dalam menyiapkan peserta didik untuk mengenal, memahami, menhayati, hingga mengimani, bertakwa, dan berakhlak mulia dalam mengamalkan ajaran agama Islam dari sumber utamanya kitab suci Al-Qur'an dan Al-Hadis, melalui kegiatan bimbingan, pengajaran, latihan, serta pengunaan pengalaman. Disertai denga tuntunan untuk mengormati penganut agama lain dalam hubungannya dengan kerukunan antar ummat beragama dalam masyarakat hingga terwujud kesatuan dan persatuan bangsa. ${ }^{23}$

Pendidikan agama Islam adalah usaha berupa bimbingan dan asuhan terhadap anak didik kelak setelah selesai pendidikannya dapat memahami dan mengamalkan ajaran agama islam serta menjadikanya sebagai padanagan hidup. ${ }^{24}$ Menurut Tayar Yusuf pendidkan agama islam adalah sebagai usaha sadar generasi tua untuk mengalihkan pengalaman, pengetahuan, kecakapan dan keterampilan kepada generasi muda agar kelak menjadi manusia muslim, bertakwa kepada Alllah SWT, berbudi pekerti luhur, dan berkepribadian yang memahami, menhayati, dan mengamalkan ajaran islam dalam kehidupannya. Sedangkang menurut A. Tafsir, pendidikan agama islam adalah bimbingan yang diberikan seseorang kepada seseorang agar ia berkembang secara maksimal sesuai dengan ajaran islam. $^{25}$

Didalam GBPP PAI di sekolah umum, dijelaskan bahwa pendidikan agama islam adalah usaha sadar untuk menyiapkan siswa dalam meyakini, memahami, menghayati, dan agama islam melalui kegiatan bimbingan, pengajaran, dan/atau latihan dengan memperhatikan tuntutan untuk menghormati agama lain dalam kerukunan anatar umat beragama dalam masyarakat mewujudkan persatuan nasional.

Dengan pengertian tersebut dapat ditemukan beberapa hal yang perlu diprhatikan dalam pembelajaran pendidikan agama islam yaitu sebagai berikut: Pertama, Pendidikan agama islam sebagai usaha sadar, yakni suatu kegiatan bimbingan, pengajaran dan/atau latihan yang dilakukan secara berencana dan sadar atas tujuan yang hendak dicapai. Kedua,

\footnotetext{
${ }^{22}$ Ibbid hlm 43

${ }^{23}$ Abdul Majid, op.cit, hlm12

${ }^{24}$ Zakiah dradjat, ilmu pendidikan islam,(bumi aksara, Jakarta, 2008), hlm 86

${ }^{25}$ Abdul Majid, op.cit, hlm12
} 
Peserta didik yang hendak disiapkan untuk mencapai tujuan dalam arti ada yang dibimbing, diajari dan/atau latihan dalam peningkatan keyakinan, pemahaman, penghayatan, dan pengalaman terhadap ajaran agama islam. Ketiga, Pendidik atau guru pendidikan agama islam yang melakukan kegiatan bimbingan, pengajaran, dan/atau latihan secara sadar terhadap peserta didiknya untuk mencapai tujuan pendidikan agama islam.

Keempat Kegiatan (pembelajaran) pendidikan agama islam diarahkan untuk meningkatkan keyakinan, pemahaman, penghayatan dan pengamalan ajaran agama islam dari peserta didik, yang di samping untuk membentuk kesalehan dan kualitas pribadi, juga sekaligus untuk membentuk kesalehan social. Dalam arti, kualitas atau kesalehan pribadi itu diharapkan mampu memancarkan ke luar dalam hubungan keseharian dengan manusia lainnya (bermasyarakat), baik yang seagama (sesame muslim), atau pun yang tidak seagama (hubungan dengan non muslim), serta dalam berbangsa dan bernegara sehinga dapat terwujud persatuan dan kesatuan nasional (ukhuwah wathaniyah) dan bahkan (ukhuwah insaniyah) persatuan dan kesatuan antar sesame manusia.

\section{Dasar-dasar Pelaksanaan Pendidikan Agama Islam}

Pelaksanaan Pendidikan agama Islam di sekolah mempunyai dasar yang kuat. Dasar tersebut menurut Zuhairini antara lain: ${ }^{26}$

a. Dasar Yuridis/Hukum

Dasar pelaksanaan pendidikan agama berasal dari perundang-undangan yang secara tidak langsung dapat menjadi pegangan dalam melaksanakan pendidikan agama di sekolah secara formal. Dasar yuridis formal tersebut antara lain: (1) Dasar ideal, yaitu dasar falsafah negara pancasila, sila pertama: Ketuhanan Yang Maha Esa. Dan (2) Dasar struktural/konstitusional, yaitu UUD'45 dalam Bab XI pasal 29 ayat 1 dan 2, yang berbunyi: 1) Negara berdasarkan atas Ketuhanan Yang Maha Esa; 2) Negara menjamin kemerdekaan tiap-tiap penduduk untuk memeluk agama masing-masing dan beribadah menurut agama dan kepercayaannya itu.

b. Dasar Religius

Yang dimaksud dengan dasar religius adalah dasar yang bersumber dari ajaran Islam. Menurut ajaran Islam pendidikan agama adalah perintah Tuhan dan merupakan perwujudan ibadah kepada-Nya.

\footnotetext{
${ }^{26}$ Abdul Majid, op.cit, hlm 13-14
} 
1. Dalam Al-Qur'an terdapat dalam Q.S. Al-Imran: 104 yang berbunyi

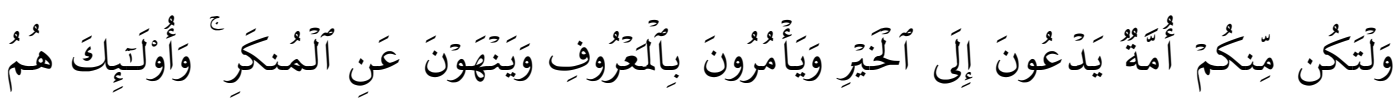

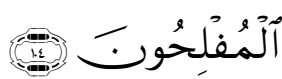

Artinya

Hendaklah ada di antara kamu segolongan umat yang menyeru kepada kebajikan, menyuruh kepada yang ma'ruf ${ }^{27}$ dan mencegah dari yang munkar ${ }^{28}$ merekalah orang-orang yang beruntung.

2. Dalam Al-Qur'an terdapat dalam Q.S. An-Nahl 125 yang berbunyi

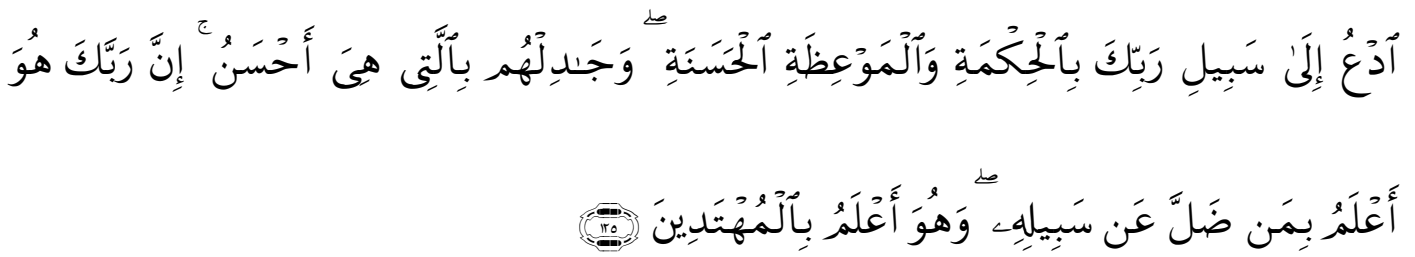

Artinya

Serulah (manusia) kepada jalan Tuhan-mu dengan hikmah ${ }^{29}$ dan pelajaran yang baik dan bantahlah mereka dengan cara yang baik. Sesungguhnya Tuhanmu Dialah yang lebih mengetahui tentang siapa yang tersesat dari jalan-Nya dan Dialah yang lebih mengetahui orang-orang yang mendapat petunjuk.

3. Dalam Al-Qur'an terdapat dalam Q.S. At-Tahrim 6 yang berbunyi

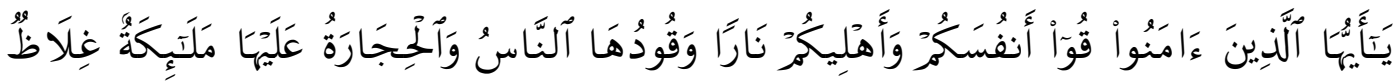

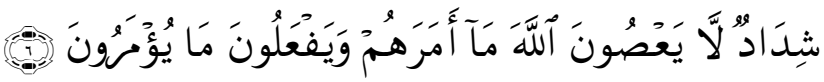

Artinya

Hai orang-orang yang beriman, peliharalah dirimu dan keluargamu dari api neraka yang bahan bakarnya adalah manusia dan batu; penjaganya malaikatmalaikat yang kasar, keras, dan tidak mendurhakai Allah terhadap apa yang

${ }^{27}$ Ma'ruf: segala perbuatan yang mendekatkan kita kepada Allah

${ }^{28}$ Munkar ialah segala perbuatan yang menjauhkan kita dari pada-Nya.

${ }^{29}$ Hikmah: ialah Perkataan yang tegas dan benar yang dapat membedakan antara yang hak dengan yang bathil. 
diperintahkan-Nya kepada mereka dan selalu mengerjakan apa yang diperintahkan.

Selain ayat-ayat tersebut, juga disebutkan dalam hadist

Artinya

Setiap anak dilahirkan itu telah membawa fithrah beragama (perasaan percaya kepada Allah SWT) maka kedua orang tuanyalah yang menjadikan anak tersebut beragama Yahudi, Nasrani, ataupun Majusi.

Dari Ayat-ayat dan Hadist tersebut, diatas memberikan pengertian kepada kita bahwa dalam ajaran Islam memang ada perintah untuk mendidik agama, baik pada keluarga maupun kepada orang lain sesuai dengan kemampuan (walaupun hanya sedikit)

\section{c. Dasar Psikologis}

Psikologis yaitu dasar yang berhubungan dengan aspek kejiwaan kehidupan bermasyarakat. Hal ini didasarkan bahwa dalam hidupnya, manusia baik sebagai individu maupun sebagai anggota masyarakat dihadapkan pada hal-hal yang membuat hatinya tidak tenang dan tidak tenteram sehingga memerlukan adanya pegangan hidup. Sebagaimana dikemukakan oleh Zuhairini dkk bahwa: Semua manusia di dunia ini selalumembutuhkan adanya pegangan hidup yang disebut agama. Mereka merasakan bahwa dalam jiwanya ada suatu perasaan yang mengakui adanya Zat yang Maha Kuasa, tempat mereka berlindung dan tempat mereka memohon pertolongan-Nya. ${ }^{30}$

Karena itu maka manusia akan selalu berusaha untuk mendekatkan diri kepada tuhan, hanya saja cara mereka mengabdi dan mendekatkan diri kepada Tuhan itu berbeda-beda sesuai dengan agama yang dianutnya. Itulah sebabnya bagi orang-orang muslim diperlukan adanya pendidikan agama islam, agar dapat mengarah fithrah mereka tersebut arah yang benar, sehingga mereka akan dapat mengabdi dan beribadah sesuai dengan ajaran islam. ${ }^{31}$

\section{Fungsi pendidikan agama islam}

Pendidikan agama Islam untuk sekolah/madrasah berfungsi sebagai berikut: (1) Pengembangan, yaitu meningkatkan keimanan dan ketakwaan peserta didik kepada Allah SWT yang telah ditanamkan dalam lingkungan keluarga. Pada dasarnya dan pertama-tama kewajiban menanamkan keimanan dan ketakwaan dilakukan oleh setiap orang tua dalam keluarga. Sekolah berfungsi untuk menumbuhkan kembangkan lebih lanjut dalam diri anak

\footnotetext{
${ }^{30}$ Abdul Majid, op.cit, hlm 14

${ }^{31}$ Abu Ahmadi, op.cit, hlm 65
} 
melalui bimbingan, pengajaran dan pelatihan agar keimanan dan ketakwaan tersebut dapat berkembang secara optimal sesuai dengan tingkat perkembangannya.(2) Penanaman nilai, sebagai pedoman hidup untuk mencari kebahagiaan hidup di dunia dan di akhirat. (3) Penyesuaian mental, yaitu untuk menyesuaikan diri dengan lingkungannya baik lingkungan fisik maupun lingkungan sosial dan dapat mengubah lingkungannya sesuai dengan ajaran agama Islam. Penyesuaian mental, yaitu untuk menyesuaikan diri dengan lingkungannya baik lingkungan fisik maupun lingkungan sosial dan dapat mengubah lingkungannya sesuai dengan ajaran agama Islam. (4) Perbaikan, yaitu untuk memperbaiki kesalahankesalahan, kekurangan-kekurangan dan kelemahan-kelemahan peserta didik dalam keyakinan, pemahaman dan pengalaman ajaran dalam kehidupan sehari-hari. (5) Pencegahan, yaitu untuk menangkal hal-hal negatif dari lingkungannya atau dari budaya lain yang dapat membahayakan dirinya dan menghambat perkembangannya menuju manusia Indonesia seutuhnya. (6) Pengajaran, tentang ilmu pengetahuan keagamaan secara umum (alam nyata dan nir-nyata), sistem dan fungsionalnya.(7) Penyaluran, yaitu untuk menyalurkan anak-anak yang memiliki bakat khusus di bidang agama Islam agar bakat tersebut dapat berkembang secara optimal sehingga dapat dimanfaatkan untuk dirinya sendiri dan bagi orang lain. ${ }^{32}$

Jadi Pendidikan agama islam di sekolah dasar berfungsi sebagai berikut sebagaimana dikemukakan oleh Bahruddin sebagai berikut: (1) Menyelamatkan generasi muda dari korban hawa nafsu karena pengaruh paham materialis-hedonisme. (2) Meningkatkan keimanan dan ketakwaan kepada Allah SWT yang telah ditanamkan dalam lingkungan keluarga. (3) Menyalamatkan anak-anak yang terjauh dari ajaran dan nilai-nilai agama.(4) Membentuk siswa agar mampu menyesuaikan diri dengan lingkungannya baik lingkungan fisik maupun lingkungan social sehinga dapat mengubah lingkungan sesuai dengan ajaran islam.(5) Sumber nilai, yaitu memberikan pedoman hidup untuk mencapai kebahagiaan hidup didunia dan akhirat.(6) Menumbuh kembangkan potensi peserta didik sekaligus mengarahkan sesuai dengan tujuan, visi dan misi pendidikan agama islam.

\section{Tujuan Pendidikan Agama Islam}

Pendidikan Agama Islam di sekolah/madrasah bertujuan untuk menumbuhkan dan meningkatkan keimanan melalui pemberian dan pemupukan pengetahuan, pengetahuan, penghayatan, pengamalan, serta pengalaman peserta didik tentang agama Islam sehingga

${ }^{32}$ Ibbid, hlm, 15-16 
menjadi manusia muslim yang terus berkembang dalam hal keimanan, ketakwaannya, berbangsa dan bernegara, serta untuk dapat melanjutkan pede jenjang pendidikan yang lebih tinggi. ${ }^{33}$ Menurut Muhaimin, PAI bertujuan agar siswa memahami, menghayati, meyakini, dan mengamalkan ajaran Islam sehingga menjadi manusia muslim yang beriman bertakwa kepada Allah SWT dan berakhlak mulia. ${ }^{34}$ Tujuan PAI harus mengacu pada penanaman nilai-nilai Islam. Hal ini dilakukan dalam rangka menuai keberhasilan hidup di dunia yang kemudian akan membuahkan kebaikan di akhirat.

Tujuan pendidikan agama islam diatas merupakan turunan dari tujuan pendidikan nasional. Yaitu Peraturan Pemerintah Republik Indonesia Nomor 19 Tahun 2005 tentang Standar Nasional Pendidikan pasal 6 ayat (1) butir a, disebutkan bahwa mata pelajaran agama dan akhlak mulai dimaksudkan untuk membentuk peserta didik menjadi menjadi manusia yang beriman dan bertakwa kepada Tuhan Yang Maha Esa serta berakhlak mulia. Akhlak mulia mencakup etika, budi pekerti, atau moral sebagai perwujudan dari pendidikan agama. ${ }^{35}$ Jadi tujuan Pendidikan Agama Islam adalah untuk membekali peserta didik dengan nilai-nilai agama supaya dapat diaplikasikan dalam kehidupan sehari-hari sehingga terbentuk manusia yang berakhlakul karimah.

Jadi tujuan pendidikan agama islam di sekolah dasar adalah Pendidkan agama islam sebagai salah satu bidang studi yang diberikan di sekolah dasar dan menduduki uraian nomor satu serta merupakan program wajib yang mesti diikuti oleh setiap siswa yang beragama islam. Tujuan pendidikan agama islam di sekolah dasar adalah untuk memberikan kemampuan dasar kepada siswa tentang agama islam untuk mengembangkan kehidupan beragama, sehingga menjadi manusia muslim yang beriman dan bertakwa kepada Allah SWT serta berakhlak mulia sebagai pribadi, anggota masyarakat, warga Negara, serta umntuk mengikuti pendidikan pada sekolah lanjutan tingkat pertama.

Pendidikan agama islam pada sekolah dasar bertujuan memberikan kemampuan dasar kepada siswa tentang agama islam untuk mengembangkan kehidupan beragama sehinga menjadi manusia muslim yang beiman dan bertakwa kepada Allah SWT serta berakhlak mulia sebagai peibadi, anggota masyarakat, warga Negara, serta umntuk mengikuti pendidikan pada sekolah lanjutan tingkat pertama.

\footnotetext{
${ }^{33}$ Ibbid, hlm, 16

${ }^{34}$ Muhaimin, op, cit, hlm, 78

${ }^{35}$ Departemen Agama RI, Undang-undang dan Peraturan Pemerintah RI tentang Pendidikan, (Jakarta: Direktorat Jendral Pendidikan Is lam Departemen Agama RI, 2006), hlm. 218.
} 


\section{Ruang Lingkup Pendidikan Agama Islam Pada Sekolah Dasar}

Secara umum ruang lingkup pendidikan agama islam meliputi keserasian, keselarasan, dan keseimbangan. Ruang lingkup pendidikan agama islam meliputi: (1) Hubungan manusia dengan Allah SWT. (2) Hubungan manusia dengan manusia. (3) Hubungan manusia dengan diri sendiri. (4) Hubungan manusia dangen mahluk lain dan lingkungannya. Sedangkan ruang lingkup pendidikan agama islam di sekolah dasar adalah: Keimanan, Ibadah, Al-Qur'an, Akhlak, Muamalah, Syariah dan Tarikh.

Salah satu diantara materi pendidikan agama islam pada sekolah dasar adalah ibadah yang didalamnya terdapat pembelajaran wudhu. Berikut ini penulis uraikan tentang berwudhu. Shalat tidak sah apabila tidak taharah (bersuci), salah satu cara bersuci untuk melaksanakan shalat adalah berwudhu. Dengan demikian bahwa, berwudhu berfungsi menghilangkan hadast kecil sehingga dapat melaksanakan shalat. ${ }^{36}$

Sebagaimana dijelaskan di atas Pendidikan Agama Islam berfungsi untuk menjaga dan menumbuhkembangkan iman anak. Materi dan kurikulum Pendidikan Agama Islam harus berdasarkan wawasan materi yang dapat menumbuhkembangkan potensi iman anak, bukan mengerosi iman. Potensi adalah fitroh, ruh, kemauan bebas, dan akal manusia. Potensi yang dimiliki oleh anak harus mendapatkan kesempatan untuk dikembangkan, Pengembangan itu bisa berupa pemeliharaan dan penjagaan potensi tersebut. Pendidikan Agama Islam terlibat dalam semua kegiatan individu dalam hal fisik, mental, psikologi, spiritual, dan mencobamenemukan keseimbangan antara kekuatan dan kelemahan seseorang.

Tujuan Pendidikan Agama Islam tidak terlepas tujuan hidup manusia dalam Islam; yaitu menciptakan pribadi- pribadi hamba Allah yang selalu bertaqwa kepadaNya dan dapat mencapai kehidupan yang berbahagia duniadan akherat. Dalam konteks sosialmasyarakat, bangsa dan negara, maka pribadi yang bertaqwa menjadi rohmatan li alalamin, baik dalam skala kecil maupun besar. Realisasi penguasaan anak didik dalam berbagai aspeknya : perasaan, kemauan, intuisi, ketrampilan atau dengan istilah lain, kognitif, afektif dan psikomotorik. Lebih terperinci dengan materi, metode dan sistem evaluasi yang disebut kurikulum, yang selanjutnya diperinci ke dalam silabus. Bahwa kurikulum dalam dunia pendidikan Islam merupakan karir masa depan siswa.

\footnotetext{
${ }^{36}$ Faqih Aunur Rahim, Hokum Islam (Graha Ilmu, Yogyakarta, 2010), hlm, 18
} 


\section{Metode Pembelajaran Pendidikan Agama Islam}

Pendidikan yang berkualitas adalah pendidikan yang ditopang oleh empat pilar yaitu 1) Learning to $\mathrm{know}^{37}$. 2) learning to $\mathrm{do}^{38}$. 3) learning to live togerher ${ }^{39}$. 4) learning . be $\mathrm{e}^{40}$. Pendidikan Agma islam merupakan salah satu mata pelajaran yang diberikan kepada siswa mulai dari tingkat dasar sampai perguruantinggi yang syarat dengan muatan nilai. Dalam konteks NKRI yang notabennya mayoritas masyarakat memeluk agama Islam, seharusnya PAI mendasari pendidikan lain, serta menjadi core/inti dan primadona bagi masyarakat, orang tua, dan peserta didik. Mata pelajaran PAI juga sebaiknya mendapat waktu yang proporsional, bukan hanya di madrasah atau sekolah yang bernuangsa Islam, tetapi disekolah umum. Demikian pula halnya dalam peningkatan mutu pendidikan, PAI harus dijadikan tolak ukur dalam membentuk wata dan kepribadian peserta didik serta membangun moral bangsa (nation character building)

Salah satu alat pendidikan agama Islam yakni metode pendidikan agama Islam, yang mana dengan menggunakan metode yang tepat maka ajaran-ajaran agama dapat diserap oleh siswa dengan sebaik-baiknya. Metode yang tepat akan menentukan efektifitas dan efisiensi pembelajaran. Seiring dengan itu seorang pendidik/ guru dituntut agar cermat memilih dan menetapkan metode apa yang tepat digunakan untuk menyampaikan materi pelajaran kepada siswa, karena dalam proses belajar mengajar dikenal ada beberapa macam metode, antara lain: metode ceramah, diskusi, tanya jawab, demonstrasi, bernyanyi, bermain peran, pemberian tugas, drill/latihan dan lain sebagainya. Semua metode tersebut dapat diaplikasikan didalam proses belajar mengajar. Ada beberapa faktor yang perlu diperhatikan dalam memilih dan mengaplikasikan sebuah metode pengajaran : 1) Tujuan yang hendak dicapai, 2) Kemampuan guru, 3) Anak didik, 4) Situasi dan Kondisi dimana

37 Learning to know yang berarti belajar untuk mendapatkan pengetahuan dan melakukan pembelajaran selanjutnya (learning to learn)

38 learning to do yaitu belajar belajar untuk memperoleh kemampuan dasar yang berhubungan dengan situasi dan tim kerja yang berbeda-beda

${ }^{39}$ learning to live togerher yaitu belajar agar mampu mengapresiasikan dan mengamalkan kondisi saling ketergantungan antar bangsa

${ }^{40}$ learning to be yaitu belajar untuk mengaktualisasikan diri sebagai individu dengan kepribadiannyayang memiliki tanggung jawab pribadi, termasuk belajar untuk menyadari dan mewujudkan diri sebagai warga negara dan hamba Allah SWT, dengan segala konsekuensinya. 
berlangsung, 5) Fasilitas yang tersedia, 6) Waktu yang tersedia, 7) Kebaikan dan Kekurangan sebuah metode ${ }^{41}$

Jadi metedo pembelajaran dapat diklasifikasikan menjadi: (1) strategi pengorganisasian, (2) strategi penyampian, dan (3) strategi pengolahan pembelajaran. Dalam kaitannya dengan pembelajaran pendidikan agama islam (PAI) strategi pengorganisasian adalah suatu metode untuk mengorganisasi isi bidang studi pendidikan agama islam yang dipilih untuk pembelajaran. Pengorganisasian isi bidang studi mengacu pada kegiatan pemilihan isi, penataan isi, pembuatan diagram, skema, format, dan sebagainya. $^{42}$ Strategi pengorganisasian dapat dibedakan menjadi strategi mikro ${ }^{43}$ dan strategi makro. $^{44}$

Strategi penyampian pembelajaran pendidikan agama islam adalah metode-metode penyampian pembelajaran pendidikan agama islam yang dikembangkan untuk membuat siswa dapat merespon dan menerima pelajaran pendidikan agama islam dengan mudah, cepat, dan menyenagkan. Karena itu, penetapan strategi penyampian perlu menerima serta merespon masukan dari peserta didik. ${ }^{45}$

Strategi pengelolaan pembelajaran adalah metode-metode untuk menata intraksi antara peserta didik dengan komponen-komponen metode pembelajaran lain, seperti pengorganisasian dan penyampian isi pembelajaran. Strategi pengelolaan pembelajaran pendidikan agama islam berupaya untuk menata intraksi peserta didik dengan memperhatiakan empat hal, yaitu: Pertama, Penjadwalan kegiatan pembelajaran yang menunjukkan tahapan-tahapan kegiatan yang harus ditempuh peserta didik dalam pembelajaran. Kedua, Pembuatan catatan kemajuan belajar peserta didik melalui penelian yang komprehensif dan berkala selama proses pembelajaran berlangsung maupun sesudahnya. Ketiga, Pengelolaan motivasi peserta didik dengan menciptakan cara-cara yang mampu meningkatkan motivasi belajar peserta didik.Control belajar yang mengacu

${ }^{41}$ Armai Arief, Pengantar Ilmu dan Metodologi Pendidikan Islam, (Jakarta: Intermasa, 2002), hlm. 109. 3

${ }_{43}^{42}$ Muhaimin, 0p, cit, hlm, 155

43 Strategi mikro adalah mengacu pada metode untuk mengorganisasikan isi pembelajaran pendidikan agama islam yang menyangkut satu konsep, prosudur, atau pringsip, dalil, hukum.

${ }^{44}$ Strategi makro adalah mengacu pada metode untuk mengorganisasikan isi pembelajaran pendidikan agama islam yang melibatkan lebih dari satu konsep, prosudur, atau pringsip, dalil, hukum

${ }^{45}$ Muhaimin, 0p, cit, hlm, 155 
kepada pemberian kebebasan untuk memilih tindakan belajar sesuai dengan karakteristik peserta didik. $^{46}$

Metode yang digunakan oleh guru untuk mengkreasi lingkunggan belajar dan mengkhususkan aktivitas dimana guru dan siswa terlibat selama proses pembelajaran berlangsung. Biasanya metode digunakan melalui salah satu strategi, tetapi juga tidak tertutup kemungkinan beberapa metode dapat divariasikan melalui strategi yang berbeda bergantung pada tujuan yang akan dicapai dan konten proses yang akan dilakukan dalam kegiatan pembelajaran. $^{47}$

Terdapat beberapa metode pembelajaran yang dapat digunakan untuk mengimplementasikan strategi pembelajaran, diantaranya: 1) ceramah 2) demonstrasi 3) diskusi 4) simulasi 5) laboratorium 6) pengalaman lapangan 7) brainstruming 8) debat 9) symposium, dan sebagainya. Untuk lebih jelasnya dapat dilihat pada bagan berikut ini.

Menurut Ibnu Khaldun metode pengajaran sepantasnya melalui tiga langkah berikut ini. Pertama, Murid belajar dengan memulai dari pengetahuan-pengetahuan umum yang sederhana dengan topik yang dipelajarinya, serta memperhatikan apakah pengetahuan tersebut sesuai dengan taraf pemikirang murid, sehingga tidak berbeda di luar kemampuan persepsinya. Begitulah murid akan sampai pada taraf pertama proses belajar yang sangat sederhana. Ibnu Khaldun menganggap langkah ini sebagai persiapan untuk memasuki langkah atau tahapan kedua.

Kedua, Guru kembali menyajikan kepada murid pengetahuan yang sama, tetapi tarafnya lebih tinggi dari taraf yang disajikannya pada langkah pertama. Pendidik mengambil point-point yang beraneka ragam dalam pelajaran itu dengan memberikan penjelasan dan keterangan tidak secara global. Dengan demikian, anak didik akan sampai pada taraf persepsi yang lebih tinggi Ketiga, Pendidik kembali untuk ketiga kalinya mengajarkan topic yang sama secara terperinci, mencakup dan mendalam pada segala segi, dan lebih terperinci, mencakup dan mendalam pada segala segi dan lebih terperinci dalam pembahasan. $^{48}$

Tidak ada satu metode yang baik untuk mencapai setiap tujuan dalam setiap situasi. Setiap metode mempunyai kebaikan dan kelemahan. Dengan sifatnya yang polivalen dan polipragmasi, guru perlu mengetahui kapan metode tepat digunakan dan kapan harus

\footnotetext{
${ }^{46}$ Ibbid, hlm, 155

47 Ibbid hlm 132

${ }^{48} \mathrm{Ibbid} \mathrm{h/m} \mathrm{132-133}$
} 
digunakan kombinasi dari metode-metode. Guru hendaknya memilih metode yang paling banyak mendatangkan hasil

Dari uraian diatas jelaslah bahwa metode mengajar itu mempengaruhi belajar. Metode mengajar guru yang kurang baik akan mempengaruhi belajar siswa yang tidak baik pula. Metode mengajar yang kurang baik itu dapat terjadi misalnya karna guru kurang persiapan dan kurang menguasai bahan pelajaran sehingga guru tersebut menyajikan tidak jelas atau sikap guru terhadap siswa dan atau terhadap mata pelajaran itu sendiri kurang baik, sehingga siswa kurang senang terhadap pelajaran atau gurunya. Akibatnya siswa malas untuk belajar ${ }^{49}$.

Guru biasa mengajar dengan metode ceramah saja. Siswa menjadi bosan, mengantuk, pasif, dan hanya mencatat saja. Guru yang progresif berani mencoba metode-metode yang baru, yang dapat membantu meningkatkan kegiatan belajar mengajar, dan meningkatkan motivasi siswa untuk belajar. Agar siswa dapat belajar dengan baik, maka metode mengajar harus diusahakan yang setepat, efesien dan efektif mungkin. ${ }^{50}$

Sedangkan dalam metode expository guru menyajikan materi yang harus dipelajari memberikan jawaban-jawaban, menyajikan prinsip-prinsip dan mengelaborasi keseluruhan isi yang harus dipelajari. Pengajaran di sini merupakan proses mengajar deduktif, dimulai dengan pemberian definisi dari konsep, prinsip-prinsip yang diajar, menjelaskannya dan memberitahukan implikasi-implikasinya. Pengajaran dengan metode belajar untuk penemuan tampak lebih bermamfaat bagi siswa dengan fleld dependent (FD) ${ }^{51}$ dikarenakan belajar di sini terjadi melalui intraksi siswa dan guru.

\section{Kesimpulan}

Pendidikan Agma islam merupakan salah satu mata pelajaran yang diberikan kepada siswa mulai dari tingkat sekolah dasar sampai keperguruantinggi yang syarat dengan muatan nilai. Dalam konteks NKRI yang notabennya mayoritas masyarakat memeluk agama Islam, seharusnya PAI mendasari pendidikan lain, serta menjadi core/inti dan primadona bagi masyarakat, orang tua, dan peserta didik.

${ }^{49}$ Slameto, Belajar \& Faktor-faktor Yang Mempengaruhi, (Penerbit Rineka Cipta, Jakarta, 2010), hlm 65

${ }^{50}$ Slameto, Belajar \& Faktor-faktor Yang Mempengaruhi, (Penerbit Rineka Cipta, Jakarta, 2010), hlm 65

51 Seseorang dengan FD menerima sesuatu lebih secara global dan men galami kesulitan dalam memisahkan diri dari keadaan sekitarnya, mereka cendrung mengenal dirinya sebagai bagian dari suatu kelompok. Dalam orientasi social mereka cendrung untuk lebih perseptif dan peka 
Salah satu alat pendidikan agama Islam sekolah dasar adalah metode pendidikan agama Islam, yang mana dengan menggunakan metode yang tepat maka ajaran-ajaran agama dapat diserap oleh siswa dengan sebaik-baiknya. Metode yang tepat akan menentukan efektifitas dan efisiensi pembelajaran. Seiring dengan itu seorang pendidik/ guru agama dituntut agar cermat memilih dan menetapkan metode yang tepat untuk menyampaikan materi pelajaran kepada siswa. Karna di dalam Islam itu sendiri juga telah diajarkan tentang metode pengajaran, karena agama Islam sesungguhnya bukan hanya satu sistem teologi semata, tetapi ia merupakan peradaban yang lengkap. Sebagaimana firman Allah dalam QS An-Nahl ayat 125

\section{Daftar Fustaka}

Abdul Majid dan Dian Andayani, 2004, Pendidikan Agama Islam Berbasis Kompetensi: Konsep dan Implementasi Kurikulum 2004, (Bandung : Remaja Rosdakarya)

Abdullah Idi \& Toto Suharto, 2006, Revitalisasi Pendidikan Islam (Yogyakarta : Tiara Wacana)

Arief, Armai, 2002, Pengantar Ilmu dan Metodologi Pendidikan Islam, (Jakarta: Intermasa) Ahmadi, Abu, 1986, Metodik Khusus Pendidikan Agama (MKPA) (Penerbit ARMICO Bandung)

Dradjat, Zakiah, 2008, Ilmu Pendidikan Islam,(bumi aksara, Jakarta)

Departemen Agama RI, 2006Undang-undang dan Peraturan Pemerintah RI tentang Pendidikan, (Jakarta: Direktorat Jendral Pendidikan Islam Departemen Agama RI)

Djamarah, Syaiful Bahri, 1994, Prestasi Belajar dan Kompetensi Guru, (Usaha Nasiaonal, Surabaya)

Fatah NC, 2012, Sejarah Pendidikan Islam. Syukur,. (Semarang: Pustaka Rizqi Putra)

Hasbullah, 2008, Dasar-dasar Ilmu Pendidikan Umum dan Agama Islam. (Jakarta: Rajawali Pers.)

H.Hamdani Ihsan, H.A.Fuad Ihsan, 2001, Filsafat Pendidikan Islam, (Bandung: Pustaka Setia)

Langgulung, Hasan, 1988, Pendidikan Islam Menghadapi Abad Ke-21, (Pustaka Al Husna, Jakarta)

Muhaimin, M. A, 2002, Paradigma Pendidikan Islam (Bandung: PT Remaja Rosdakarya) 
Majid, Abdul, 2012, Belajar dan Pembelajaran Pendidikan Agama Islam, (Penerbit PT Remaja Rosdakarya Bandung)

Rahim, Faqih Aunur, 2010, Hokum Islam (Graha Ilmu, Yogyakarta)

Roestiyah NK, Strategi Belajar Mengajar, (Jakarta: Rineka Cipta, 2008)

Ramayulis, 1990, Metodologi Pengajaran Agama Islam, (Jakarta: Kalam Mulia)

Suharso dan Ana Retnoningsih, 2009, Kamus Besar Bahasa Indonesia, (Semarang: Widya Karya)

Sanusi Uwes, 2003, Visi dan Pondasi Pendidikan( Dalam Perspektif Islam), (Jakarta: Logos Wacana Ilmu)

Sudjana, Nana, 1996, CBSA, Cara Belajar Siswa Aktif dalam Proses Balajar Mengajar (Bandung, Sinar Baru Algensindo)

Slameto, Belajar \& Faktor-faktor Yang Mempengaruhi, (Penerbit Rineka Cipta, Jakarta, 2010)

UU SISDIKNAS 2003 (Bandung: Citra Umbara, 2006) 